\title{
New floristic records from Central Europe 6 (reports 81-98)
}

\author{
Matej Dudášs ${ }^{1}$ (ed.), Pavol Eliáš ${ }^{2}$, Pavol Eliáš jun. ${ }^{3}$, Artur Górecki ${ }^{4}$, Matúš Hrivnák ${ }^{5}$, Richard \\ Hrivnák $^{6}$, Miroslava Malovcová-Staníková7, Margaréta Marcinčinová1 \& Artur Pliszko ${ }^{4}$ \\ ${ }^{1}$ Department of Botany, Institute of Biology \& Ecology, Faculty of Science, P. J. Šafárik University, \\ Mánesova 23, SK-041 54 Košice, Slovakia, dudas.mato@gmail.com \\ 2 Generála Goliána 8, SK-97102, Trnava, Slovakia, pavol.elias149@gmail.com \\ ${ }^{3}$ Department of Environment and Biology, Slovak University of Agriculture, Tr. A. Hlinku 2, SK-949 76, \\ Nitra, Slovakia, pavol.elias.jun@gmail.com \\ ${ }^{4}$ Institute of Botany, Faculty of Biology, Jagiellonian University, Gronostajowa 3, 30-387 Kraków, \\ Poland, artur.pliszko@uj.edu.pl; artur.gorecki@doctoral.uj.edu.pl \\ ${ }^{5}$ Department of Phytology, Faculty of Forestry, Technical University in Zvolen, T. G. Masaryka 24, SK- \\ 96053 Zvolen, Slovakia, matus.hrivnak@tuzvo.sk \\ ${ }^{6}$ Institute of Botany, Plant Science and Biodiversity Center, Slovak Academy of Sciences, Dúbravská \\ cesta 9, SK-845 23 Bratislava, Slovakia, richard.hrivnak@savba.sk \\ 7 Homeland museum Hlohovec, Františkánske námestie 1, SK-920 01, Hlohovec, Slovakia, \\ malovcova.miroslava@zupa-tt.sk
}

Dudáš M. (ed.), Eliáš P., Eliáš P. jun., Górecki A., Hrivnák M., Hrivnák R., Malovcová-Staníková M., Marcinčinová M. \& Pliszko A. (2020): New floristic records from Central Europe 6 (reports 81-98). - Thaiszia - J. Bot. 30 (2): 209-220.

Abstract: The presented sixth part of the series includes 18 new chorological records of vascular plants, five from Poland and thirteen from Slovakia. In Poland, the first spontaneous occurrence of Clinopodium nepeta subsp. nepeta outside cultivation is reported from Kraków. Also new localities of Euphorbia maculata, Panicum capillare, Plantago coronopus and Symphyotrichum ciliatum from southern Poland were found. In Slovakia, new records of alien Cardamine occulta, Lindernia dubia, Nigella damascena, Pistia stratiotes (with map of known records), Sagittaria latifolia, Senecio inaequidens, Silybum marianum and Vinca major were done as well as autochthonous Cotoneaster melanocarpus, Herniaria hirsuta, Verbascum speciosum and Xeranthemum annuum.

Keywords: chorology, vascular plants, new findings, Poland, Slovakia, native species, alien, red list species. 
This is an ongoing report in the established series dealing with new chorological data on higher vascular plants in Central Europe (for details, see Thaiszia - J. Bot. 28 (1), pp. 79-80, 2018).

The nomenclature of taxa follows the Euro+Med PlantBase (Euro+Med 2006-) and/or Chromosome number survey of the ferns and flowering plants of Slovakia (Marhold et al. 2007), herbarium acronyms follow Thiers (2020+).

The publication includes contributions by M. Dudáš (81-82), P. Eliáš jun. \& $P$. Eliáš (83-86), R. Hrivnák (87-89), R. Hrivnák \& M. Hrivnák (90), M. Malovcová-Staníková (91), M. Marcinčinová (92-93) and A. Pliszko \& A. Górecki (94-98) arranged alphabetically.

\section{Matej Dudáš (reports 81-82)}

\section{SK}

81. Sagittaria latifolia Willd.: the Východoslovenská nízina Lowland, river Trnávka between Trebišov and Hraň, scattered and on few places frequent in $9 \mathrm{~km}$ long part of the river, $100 \mathrm{~m}$, from $48^{\circ} 36^{\prime} 34.77^{\prime \prime} \mathrm{N} 21^{\circ} 44^{\prime} 5.08^{\prime \prime} \mathrm{E}$ to $48^{\circ} 32^{\prime} 46.2^{\prime \prime} \mathrm{N} 21^{\circ} 47^{\prime} 30.4^{\prime \prime} \mathrm{E}$, 7396c, 7496a+b+d, 26. 7. 2020, M. Dudáš, KO 35698-35699.

North-american alien species known only from three localities in southern part of Slovakia (Nobis et al. 2019; Dudáš et al. 2019). First record of the garden escaping in the Východoslovenská nížina Lowland. It colonizes both banks of the Trnávka river from the town of Trebišov to Hraň village in $9 \mathrm{~km}$ long part of the river. It is frequent in few places and its invasive potential became dangerous. The southernmost plants were recorded over weir (east from Hraň) on downstream part of the Trnávka river before its flow into the Ondava river. The origin is perhaps located in the garden settlement in south-eastern part of Trebišov.

82. Vinca major L.: the Strážovské vrchy Mts., Omastiná, northern part of the village, garden escapee, established in two separate neighbouring areas, very frequent along the road, $360 \mathrm{~m}, 48^{\circ} 46^{\prime} 45.1^{\prime \prime} \mathrm{N} 18^{\circ} 23^{\prime} 25.9^{\prime \prime} \mathrm{E}, 7276 \mathrm{a}, 7.5 .2020$, M. Dudáš, KO 35530, photodocumentation.

Mediterranean species; in Slovakia it is known as a garden escapee from less than 4 locations (Medvecká et al. 2012). The first report on the garden escaping in Slovakia concernes the proximity of the town of Modra in the foothill of the Male Karpaty Mts (Hajdúk 1975). In northern part of Omastiná village it was found in two separate areas. The first one is located on the regulated stream right embankment (monodominant area of ca $10 \mathrm{~m}^{2}$ ) and the second one along the road over a ditch (left embankment) with the colonization of the nearest hornbeam forest on the area ca $12 \mathrm{~m}^{2}$. 


\section{Pavol Eliáš jun. \& Pavol Eliáš (reports 83-86)}

\section{SK}

83. Cotoneaster melanocarpus (Bunge) Loudon: the Pohronský Inovec Mts., the Vel'ký Inovec hill, 3 individuals on rocks at the top of hill, $892 \mathrm{~m}, 48^{\circ} 24^{\prime} 36.2^{\prime \prime} \mathrm{N}$ $18^{\circ} 32^{\prime} 36.8^{\prime \prime E}, 7577 c, 7.8$. 2020, P. Eliáš jun. \& P. Eliáš, NI. - the Pohronský Inovec Mts., Obyce, on the rocks of a rocky ridge towards the top of Skerešov hill, a single individual, $419 \mathrm{~m}, 48^{\circ} 25^{\prime} 55.6^{\prime \prime} \mathrm{N} 18^{\circ} 28^{\prime} 22.9^{\prime \prime E}, 7576 \mathrm{~d}, 2$ 2. 6. 2009, P. Eliáš jun., NI.

The species is rare in this area. From the phytogeographical district of Pohronský Inovec, there are only two records of $C$. melanocarpus from the surroundings of Hronský Beňadik town [(Baranec 1992 ut C. nigra (Ehr.) Fries] and one record from the surroundings of the Čaradice village (Benčat' et al. 1982, p. 86), which is probably a mistake because the edge of the oak-beech forest is mentioned as a habitat. However, $C$. melanocarpus occupies rocky ridges, slopes and cliffs. From the top of the Vel'ký Inovec hill, a single individual of $C$. integerrimus is mentioned (Benčat' et al. 1982 , p. 85). We believe that this one is from the same $C$. melanocarpus plants as we found here, but the species was not correctly identified by Benčat' et al. (l. c.) because it is a taxonomically complicated genus (Kšiňan et al. 2020).

84. Herniaria hirsuta L.: the Podunajská nížina Lowland, Bratislava, Rudnayovo námestie square and Panská ulica street, $145 \mathrm{~m}, 48^{\circ} 08^{\prime} 29.7^{\prime \prime} \mathrm{N} 17^{\circ} 06^{\prime} 20.0^{\prime \prime} \mathrm{E}, 7868 \mathrm{~d}$, 18. 7. 2017, P. Eliáš, NI.

A new locality of the rare annual species evaluated in the category "endangered" (Eliáš et al. 2015) and at the same time the verification of its occurrence in Bratislava, where the lastest data were pulished in 1998 (Valenta 1998 BRA in Eliáš jun. 2012). Herniaria hirsuta prefers disturbed habitats of anthropogenic origin - railway embankments, sidewalk edges, country roads, vineyards and fields on sandy and clay soils. The species occurs in Europe, West Asia and North and East Africa, in Slovakia only in the western part (Sutorý 1980; Eliáš jun. I. c.).

85. Senecio inaequidens D.C.: the Podunajská nížina Lowland, Nitra, A. Hlinku Street, a single individual at the road edge, $137 \mathrm{~m}, 48^{\circ} 18^{\prime} 29.4^{\prime \prime} \mathrm{N} 18^{\circ} 05^{\prime} 37.3^{\prime \prime} \mathrm{E}, 7674 \mathrm{~d}, 30.9$. 2019, P. Eliáš jun., NI.

No data of $S$. inaequidens have been known in the close surrounding of Nitra yet. Senecio inaequidens, an alien weed from South Africa, was introduced into Europe at the end of the $19^{\text {th }}$ century (Kaplan et al. 2018). In Slovakia, the species is distributed especially in W and SW part (Jehlík 1998; Feráková 2002). The number of sites seems to be gradually growing, with the species spreading mainly by the road transport (Kocián 2016). As it is evident from the published data of the adjacent countries, the species is spreading eastwards (Pliszko 2017; Haszonits \& Schmidt 2018). 
86. Verbascum speciosum Schrad.: the Podunajská nížina Lowland, Vlkanovo, along the road to the farmstead and adjacent grassland, some hundreds of individuals, 116 - 118 m, 4756'31.8"N 18¹4'21.3"E, 8075c, 15. 7. 2020, P. Eliáš jun., NI.

New locality of the relatively rare Verbascum species, it is evaluated in the category "near threated" (NT) in actual version of the Slovak Red List of ferns and flowering plants (Eliáš et al. 2015). The closest locality of the species is near the Dvory nad Žitavou railway station (Holub \& Eliáš 1999), we believe $V$. speciosum most likely spread to this new locality from it. The origin of the species in Slovakia is not clear; Králik (2009) believes that it came to this region in the $16^{\text {th }}$ century as a medicinal plant in connection with the arrival of Croats to Central Europe due to the expansion of the Ottoman Empire.

\section{Richard Hrivnák (reports 87-89)}

\section{SK}

87. Cardamine occulta Hornem.: the Lučenská kotlina Basin, Lučenec town, centre of the town, the garden shop on the J. M. Hurbana street, $184 \mathrm{~m}, 48^{\circ} 19^{\prime} 30.39^{\prime \prime} \mathrm{N}$ $19^{\circ} 40^{\prime} 18.44 " E, 7684 c$, 4. 5. 2019, R. Hrivnák, SAV. - the Lučenská kotlina Basin, Lučenec town, centre of the town, garden shop on the Mieru street, $185 \mathrm{~m}$, 48¹9'59.29"N 1940'15.74"E, 7684c, 4. 5. 2019, R. Hrivnák, SAV.

Cardamine occulta is an Asian weedy species first mentioned from the territory of Slovakia in 2002 and recently known from 16 localities mainly in the western, and occasionally in the Central Slovakia (Prievidza and Zvolen towns; Šlenker et al. 2019). On both the new localities, the individuals of the species grew in flower pots.

88. Lindernia dubia (L.) Pennel: the Lučenská kotlina Basin, Lučenec town, Water reservoir Ladovo, exposed bottom in the north-western part of the reservoir, $193 \mathrm{~m}$, $48^{\circ} 20^{\prime} 4.4^{\prime \prime} \mathrm{N} 19^{\circ} 37^{\prime} 30.5^{\prime \prime E}, 7683 d$, 7. 8. 2019, R. Hrivnák, SAV.

This alien species, native to North America, was found in the territory of Slovakia recently (Hrivnák et al. 2016) and it is known from 3 localities: near Trenč, Štiavnické Bane and Štúrovo (Schmotzer 2015; Kochjarová et al. 2015; Dítě \& Dítě 2019). Similarly to the previous findings, the vegetation on the newly found locality near Lučenec town was classified into vegetation of exposed bottom of IsoëtoNanojuncetea Br.-Bl. et Tx. in Br.-Bl. et al. 1952. The population counted ca 100-200 individuals in the time of observation. The next year (2020), when the whole reservoir was drained, L. dubia grew in various parts of the reservoir bottom in vegetation of the classes Isoëto-Nanojuncetea and later Bidentetea Tx. et al. ex von Rochow 1951; the population counted thousands of individuals.

89. Pistia stratiotes L.: the Podunajská rovina Lowland, Kolárovo town, south of the town, near the road to Kameničná village, road ditch filled by thermal water from closed artificial thermal spring, $112 \mathrm{~m}, 47^{\circ} 51^{\prime} 30.5^{\prime \prime} \mathrm{N} 18^{\circ} 0^{\prime} 19.1^{\prime \prime} \mathrm{E}, 8174 \mathrm{a}, 5.9 .2017$, R. Hrivnák \& K. Bubíková, SAV. - the Podunajská rovina Lowland, Nové Zámky, north- 
eastern margin of the town, Nitra river arm below a thermal swimming pool, $128 \mathrm{~m}$, $47^{\circ} 59^{\prime} 46.1^{\prime \prime N} 18^{\circ} 11^{\prime} 3.4 " E, 8075 a, 24.10 .2017$, R. Hrivnák, SAV.

Alien aquatic plant, first time recorded in Slovakia in 2007 (Tóthová et al. 2007) with the occurrence in south-western Slovakia (Hrivnák et al. 2019) and strong concentration on the Čierna voda river near Král'ová pri Senci (Ružičková et al. 2020). Two newly presented localities were also found in the Podunajská rovina lowland, however, the distribution area of the species in Slovakia expanded more to east (Fig. 1).

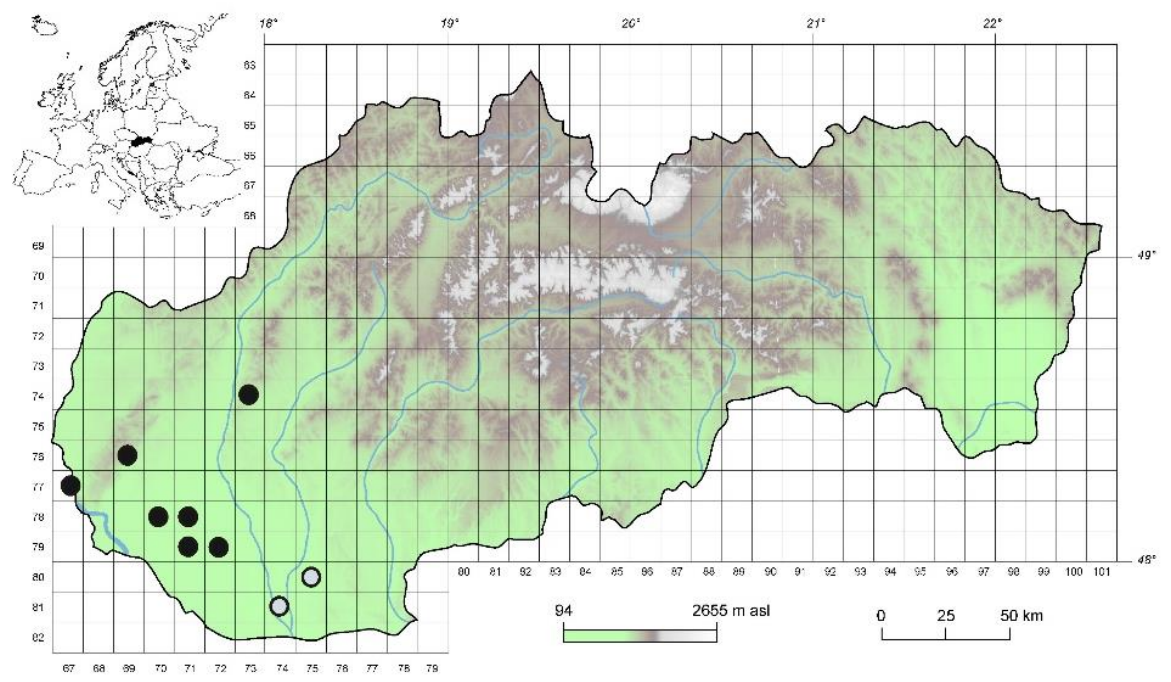

Fig. 1 Recent records of Pistia stratiotes in Slovakia (black circles - previously mentioned localities, shaded circle - new findings).

\section{Richard Hrivnák \& Matúš Hrivnák (report 90)}

\section{SK}

90. Sagittaria latifolia Willd.: the Rimavská kotlina Basin, Číž - spa, Barický potok stream near the spa house Detva, 169 m, 48¹8'51.46"N 20¹6'46.38"E, 7687d, 3. 10. 2019, R. Hrivnák \& M. Hrivnák, photodocumentation.

Alien macrophyte species was known only from three localities in southern part of Slovakia (Nobis et al. 2019; Dudáš et al. 2019). The species growth on the locality in Číz - spa covered ca $10 \mathrm{~m}^{2}$ across the stream watercourse. The species occurrence is probably related to its planting in the closed small ponds hydrologically connected with the stream. 


\section{Miroslava Malovcová-Staníková (report 91)}

\section{SK}

91. Xeranthemum annuum L.: the Nitrianska pahorkatina Hills, Posádka - part of the Dvorníky village, Verešovo land area, near Bereg Garden Settlement, $180 \mathrm{~m}$, $48^{\circ} 21^{\prime} 56.2^{\prime \prime} \mathrm{N} 17^{\circ} 45^{\prime} 56.2^{\prime \prime} \mathrm{E}, 7672 \mathrm{~b}, 9.7 .2020$, M. Malovcová, photodocumentation.

Probably the first record from this locality.

\section{Margaréta Marcinčinová (reports 92-93)}

\section{SK}

92. Nigella damascena L.: the Košická kotlina Basin, Košice, City District Západ, Medická 4 street, only single flowering plant at the roadside, disturbed grass-plot, $240 \mathrm{~m}, 48^{\circ} 43^{\prime} 7.323^{\prime \prime} \mathrm{N} 21^{\circ} 14^{\prime} 33.240^{\prime \prime} \mathrm{E}, 7293 \mathrm{c}$, 3. 6. 2020, M. Marcinčinová, KO: 35710.

Note of editor: casual garden escapee. According to Medvecká et al. (2012) it is considered a neophyte species in Slovakia.

93. Silybum marianum (L.) P. Gaertn.: the Košická kotlina Basin, Košice, City District Západ, Považská 1 street, single flowering plant next to building, ruderalized lawn, 240 m, 4843'4.627"N 21ำ'26.983"E, 7293c, 25. 5. 2020, M. Marcinčinová, photodocumentation.

Note of editor: casual garden escapee. According to Medvecká et al. (2012) it is considered a neophyte species in Slovakia. In the fields around Košice it has not been cultivated.

\section{Artur Pliszko \& Artur Górecki (reports 94-98)}

$\underline{P L}$

94. Clinopodium nepeta (L.) Kuntze subsp. nepeta: southern Poland, Lesser Poland Province, Kraków, Lwowska Street, one flowering plant in a gap between the sidewalk and sewage gully, near the flowerbed of roses, $201 \mathrm{~m}, 50^{\circ} 02.646^{\prime} \mathrm{N}$ $19^{\circ} 57.502 '$ 'E, 11. 9. 2020, A. Pliszko, KRA 0557639.

Clinopodium nepeta subsp. nepeta, a perennial plant of Lamiaceae, is native to Southern and South-Central Europe, Transcaucasia, Lebanon-Syria and Iran. It was introduced to Western and North-Central Europe, North America and New Zealand (Plants of the Word online 2020). It occurs in Pinus-Quercus forests, phrygana, grasslands, dry meadows, cliffs, screes, dry river bed banks and ruderal habitats, in mountains and plains (Morales \& Luque 1997; Alan \& Ocak 2009). In Europe, naturalization of $C$. nepeta subsp. nepeta has been observed in Belgium (Randall 2017 and reference therein). It was also recorded as a casual alien in the Czech Republic (Pyšek et al. 2012). In Poland, as in other countries, it is an ornamental, 
medicinal and edible plant cultivated in gardens and flowerbeds, mostly in urban areas. This is the first spontaneous occurrence of $C$. nepeta subsp. nepeta outside cultivation in Poland. It was found about $40 \mathrm{~m}$ from the nearest place of its cultivation (flowerbed with other ornamentals). Currently, it should be classified as a casual alien plant in the Polish flora. It was identified based on morphological features provided by Bacchetta \& Brullo (2005) and Alan \& Ocak (2009).

95. Euphorbia maculata L.: southern Poland, Lesser Poland Province, Zabierzów, several dozen flowering plants in the gaps between sidewalk stones, $225 \mathrm{~m}$, $50^{\circ} 07.067$ 'N $19^{\circ} 48.034$ 'E, 8. 10. 2020, A. Pliszko \& A. Górecki, KRA 0557622.

Euphorbia maculata, an annual plant of Euphorbiaceae, is native to North America. It was introduced to South America, Europe, Asia, Africa and Australia (Randall 2017 and references therein). It usually occurs in open habitats such as grasslands, fields, gardens, lawns and roadsides (Eliáš jun. 2009; Pahlevani \& Riina 2011; Urbisz 2019 and others). In Poland, it is a very rare species known from four localities in southern and central parts of the country (Zając \& Zając 2019). According to Tokarska-Guzik et al. (2012), E. maculata belongs to established alien species (kenophytes) in the Polish flora. It has been recorded as a weed in the botanical gardens in Kraków and Wrocław, as well as in a monastery garden in Ożarów Mazowiecki. Recently, it was found between sidewalk stones in a tram stop in Katowice (Urbisz 2019 and references therein). This is the second record of E. maculata in Lesser Poland Province. It was identified based on morphological features provided by Pahlevani \& Riina (2011) and Verloove (2013).

96. Panicum capillare L.: southern Poland, Lesser Poland Province, Brzegi near Kraków, several hundred flowering plants on roadside verges and banks of fish ponds near aggregate mine, $195 \mathrm{~m}, 50^{\circ} 02.104^{\prime} \mathrm{N} 20^{\circ} 05.116^{\prime} \mathrm{E}, 20.9 .2020$, A. Pliszko, KRA 0557631, 0557632 - Kraków, near Płaszów, five flowering plants on a wasteland, 208 $\mathrm{m}, 50^{\circ} 01.623^{\prime} \mathrm{N} 20^{\circ} 00.247^{\prime} \mathrm{E}, 16.9$. 2020, A. Pliszko \& A. Górecki, KRA 0557630.

Panicum capillare, an annual species of Poaceae, is native to North America. It was introduced to South America, Europe, Asia, Africa and Australia (Clements et al. 2004; Randall 2017 and references therein). It occurs in disturbed and eroded soils of floodplains and beaches, loess prairies and burned Pinus banksiana Lambert forests. It also occurs in anthropogenic habitats such as cultivated fields, meadows, gardens, and waste areas, roadsides, clearings, ditches and abandoned fields (Clements et al. 2004 and references therein). In Europe, $P$. capillare is naturalized in many countries (e.g., Portugal, Spain, Croatia, Romania, Germany, the Czech Republic, Slovakia, Lithuania and Belarus) (Randall 2017 and references therein). In Poland, it is usually treated as an ornamental plant cultivated in gardens (Mirek et al. 2002). However, Nobis \& Nobis (2006) suggested that $P$. capillare is an established alien plant in south-eastern Poland. The status and distribution of $P$. capillare in Poland are neglected, considering the data provided by Tokarska-Guzik et al. (2012) and Zając \& Zając (2019). This is the next record suggesting that $P$. capillare is an 
established alien plant in the Polish flora. The species was identified using morphological features provided by Clements et al. (2004) and Király \& Alegro (2015).

97. Plantago coronopus L.: southern Poland, Lesser Poland Province, Modlniczka near Kraków, several dozen flowering plants on a verge of highway, $243 \mathrm{~m}$, $50^{\circ} 06.378^{\prime} \mathrm{N} 19^{\circ} 50.923^{\prime} \mathrm{E}$ and several dozen flowering plants in a highway median, $242 \mathrm{~m}, 50^{\circ} 06.376^{\prime} \mathrm{N} 19^{\circ} 50.997^{\prime} \mathrm{E}, 3.10 .2020$, A. Pliszko \& A. Górecki, KRA 0557624, $0557625,0557626$.

Plantago coronopus, an annual, biennial or perennial species of Plantaginaceae, is native to Europe, Northern Africa, Western and Central Asia. It was introduced to North America, South America, South Africa, and Australia (CABI 2020). It is a halophyte occurring mostly along coastal areas. In Poland, it is a native species, critically endangered and strictly protected by law (Sotek 2014; Rozporządzenie... 2014). Its native geographical range in Poland is restricted to a small area along the Baltic coast, in the north-western part of the country (Sotek 2014; Zając \& Zając 2019). However, it was introduced to other regions in north-western and southwestern Poland where it is found in anthropogenic habitats (Sadowska \& Żółkoś 2011; Zając \& Zając 2019), especially on roadside verges of highways which are regularly treated with salt during winters (Nowak \& Nowak 2018). This is the first record of $P$. coronopus in Lesser Poland Province. Further spread of the species along highways in Poland is expected. The species was identified following Rutkowski (2004).

98. Symphyotrichum ciliatum (Ledeb.) G. L. Nesom: southern Poland, Lesser Poland Province, Brzegi near Kraków, several dozen flowering plants on a roadside verge, $190 \mathrm{~m}, 50^{\circ} 01.906^{\prime} \mathrm{N} 20^{\circ} 05.688^{\prime} \mathrm{E}, 20.9 .2020$, A. Pliszko, KRA 0557644. - several tens of thousands flowering specimens on a wet wasteland near aggregate mine, $194 \mathrm{~m}$, $50^{\circ} 01.829^{\prime} \mathrm{N} 20^{\circ} 04.403$ 'E, 2. 10. 2020, A. Pliszko \& A. Górecki, KRA 0557645, 0557646 - Kryspinów near Kraków, several dozen flowering specimens in a ruderal ground near the barrage on the Vistula river, $202 \mathrm{~m}, 50^{\circ} 01.899^{\prime} \mathrm{N} 19^{\circ} 49.105^{\prime} \mathrm{E}, 25$. 9. 2020, A. Pliszko, KRA 0557643 - Kraków, Łagiewniki, one flowering plant on a verge of renovated road, $211 \mathrm{~m}, 50^{\circ} 01.275^{\prime} \mathrm{N} 19^{\circ} 55.925^{\prime} \mathrm{E}, 27$. 9. 2020, A. Pliszko, KRA 0557640 - Kraków near Bonarka, several tens of thousands flowering plants on a wet wasteland, $223 \mathrm{~m}, 50^{\circ} 01.522^{\prime} \mathrm{N} 19^{\circ} 56.835^{\prime} \mathrm{E}, 26$. 9. 2020, A. Pliszko \& A. Górecki, KRA $0557641,0557642$.

Symphyotrichum ciliatum, an annual species of Asteraceae, is native to North America and Eurasia (Brouillet et al. 2006). It occurs on moist, brackish soils, in prairies, steppes and salt marshes. It is also found in anthropogenic habitats such as irrigation channels, winter-salted highways, railroads and waste grounds (Brouillet et al. 2006; Sârbu \& Smarandache 2015). It was introduced to Western and Central Europe (i.e., Belgium, Slovakia, Poland, Moldova and Romania) (Randall 2017 and references therein). Its invasive status has been confirmed in Romania (Sârbu \& 
Smarandache 2015). In Poland, S. ciliatum is treated as an established alien (kenophyte) and a potentially invasive species (Tokarska-Guzik et al. 2012). It is rarely distributed in south-eastern part of the country (Zając \& Zając 2019). It is usually found in ruderal habitats such as roadside verges, railway areas, construction sites, quarries, and wastelands (Bróż \& Podgórska 2005; Szymański 2010; StadnickaFutoma \& Oklejewicz 2013; Nobis \& Pliszko 2016). It has been presented in Kraków since the 1980s (Guzik 2003). The new records suggest that S. ciliatum is locally invasive in wet ruderal habitats in Kraków and Brzegi. Identity of S. ciliatum was confirmed using morphological features provided by Bróż \& Podgórska (2005) and Brouillet (2006).

Note of editor: In Slovakia, it was first reported from Košice (eastern Slovakia) by Mikoláš (1988) under name Brachyactis ciliata (Ledeb.) Ledeb. and in the present, it spreads inconspicuously and slowly along roads within the town (Dudáš et al. 2020).

\section{Acknowledgement}

The research of P. Eliáš jun. was supported by grant VEGA No. 1/0047/19.

\section{References}

Alan S. \& Ocak A. (2009): Taxonomical and morphological studies on the genus Calamintha Miller (Lamiaceae) in Turkey. - Biol. Divers. Conserv. 2: 125-143.

Bacchetta G. \& Brullo S. (2005): Calamintha sandaliotica (Lamiaceae) a new species from Sardinia. - An. Jardín Bot. de Madrid 62(2): 135-141.

Baranec T. (1992): Cotoneaster Medicus. - In Bertová L. (ed.): Flóra Slovenska IV/3. - Veda, Bratislava. p. 452-462.

Benčat' F., Požgaj J. \& Šmihulová A. (1982): Rozšírenie a ekológia drevín v pohoriach Tríbeč a Pohronský Inovec. - Acta Dendrobiol. 5: 1-277.

Brouillet L., Semple J. C., Allen G. A., Chambers K. L. \& Sundberg S. D. (2006): Symphyotrichum Nees. - In: Flora of North America Editorial Committee (eds.), Flora of North America, vol. 20. - Oxford University Press. - New York-Oxford, pp. 465-539.

Bróż E. \& Podgórska M. (2005): Symphyotrichum ciliatum (Brachyactis ciliata) (Asteraceae) w Polsce. - Fragm. Flor. Geobot. Polonica 12(2): 291-299.

CABI (2020): Plantago coronopus (Buck's-horn plantain). Invasive Species Compendium. Published on the internet https://www.cabi.org/isc/datasheet/109678\#todistribution [accessed 03 October 2020].

Clements D. R., DiTommaso A., Darbyshire S. J., Cavers P. B. \& Sartonov A. D. (2004): The biology of Canadian weeds. 127. Panicum capillare L. - Can. J. Plant Sci. 84: 327-341. DOI: 10.4141/P02-147

Dítě D. \& Dítě Z. (2019): Ďalší nový výskyt lindernie pochybnej (Lindernia dubia) na Slovensku. - Bull. Slov. Bot. Spoločn. 41: 69-76.

Dudáš M. (ed.), Malovcová-Staníková M., Pliszko A., Schieber B. \& Zieliński J. (2019): New floristic records from Central Europe 4 (reports 41-53). - Thaiszia - J. Bot. 29 (2): 231237. doi.org/10.33542/TJB2019-2-08 
Dudáš M. (ed.), Eliáš P., Eliáš P. jun., Hrivnák M., Hrivnák R., Marcinčinová M., Mokráň M., Pliszko A., Slezák M. \& Veverka M. (2020): New floristic records from Central Europe 5 (reports 54-79). - Thaiszia - J. Bot. 30 (1): 103-114. doi.org/10.33542/TJB2020-1-08

Eliáš P. jun. (2009): First record of Euphorbia maculata L. (Euphorbiaceae) in Slovakia. Thaiszia - J. Bot. 19: 21-25.

Eliáš P. jun. (2012): Herniaria L. - In Goliašová K. \& Michalková E. (eds.): Flóra Slovenska VI/3. - Veda, Bratislava. p. 108-119.

Eliáš P. jun., Dítě D., Kliment J., Hrivnák R. \& Feráková V. (2015): Red list of ferns and flowering plants of Slovakia, 5th edition (October 2014). - Biologia 70/2: 218-228.

DOI: 10.1515/biolog-2015-0018

Euro+Med (2006-): Euro+Med PlantBase - the information resource for Euro-Mediterranean plant diversity. Published on the Internet http://ww2.bgbm.org/EuroPlusMed/ [accessed October 2019]

Feráková V. (2002): Nové lokality zriedkavých neofytov flóry Slovenska. - Bull. Slov. Bot. Spoločn. 24: 113-116.

Guzik J. (2003): Hałda Huty im. T. Sendzimira w Krakowie - miejscem występowania interesujących obcych gatunków roślin. - Arch. Ochr. Środ. 29(2): 13-19.

Hajdúk J. (1975): Vinca major L. na úpätí Malých Karpat pri Modre. - Zpr. čs. bot. Společ. (Praha) 10: 39-40.

Haszonits G. \& Schmidt D. (2018): A potenciálisan inváziós vesszős aggófú (Senecio inaequidens DC.) aktuális elterjedése Magyarországon. - Kitaibelia 23: 179-187.

Holub J. \& Eliáš P. (1999): Verbascum speciosum Schrader. - In Čeřovský J., Feráková V., Holub J., Maglocký Š. \& Procházka F. (eds.): Červená kniha ohrozených a vzácnych druhov rastlín a živočíchov SR a ČR Vol. 5. Vyššie rastliny. - Príroda, Bratislava. p. 396.

Hrivnák R., Kochjarová J., Šumberová K. \& Schmotzer A. (2016): Lindernia dubia (Scrophulariaceae): a new alien species to the Slovak flora. - Biologia 71: 281-286. doi.org/10.1515/biolog-2016-0039

Hrivnák R., Medvecká J., Baláži P., Bubíková K., Ot'ahel'ová H. \& Svitok M. (2019): Alien aquatic plants in Slovakia over 130 years: historical overview, current distribution and future perspectives. - NeoBiota 49: 37-56. doi.org/10.3897/neobiota.49.34318

Jehlík V. (1998): Senecio inaequidens a Atriplex heterosperma - nové invazní rostliny také na Slovensku. - In Eliáš P. (ed.): Invázie a invázne organizmy. - Slovenský národný komitét SCOPE \& Katedra ekológie FZKI SPU Nitra, Nitra. p. 23.

Kaplan Z., Danihelka J., Chrtek J. Jr., Prančl J., Ducháček M., Ekrt L., Kirschner J., Brabec J., Zázvorka J., Trávníček B., Dřevojan P., Šumberová K., Kocián P., Wild J. \& Petřík P. (2018): Distributions of vascular plants in the Czech Republic. Part 7. - Preslia 90: 425-531. DOI: 10.23855/preslia.2018.425

Király G. \& Alegro A. (2015): Re-evaluation of the Panicum capillare complex (Poaceae) in Croatia. - Acta Bot. Croat. 74(1): 173-179.

Kocián P. (2016): The first records of Senecio inaequidens along motorways in Poland and Slovakia. - Acta Mus. Siles. Sci. Natur. 65: 129-133. DOI: 10.1515/cszma-2016-0016

Kochjarová J., Hrivnák R. \& Letz D.R. (2015): Flóra a vegetácia na obnaženom dne vypustených vodných nádrží v okolí Zvolena a Banskej Štiavnice. - Bull. Slov. Bot. Spoločn. 37: 87-102.

Králik T. (2009). Divozel úhl'adný (Verbascum speciosum) - nepôvodný druh našej flóry? Bull. Slov. Bot. Spoločn. 31: 21-34.

Kšiňan S., Ďurišová L'. \& Eliáš P. jun. (2020): Morphological characteristics as a key attribute for a successful determination of selected Cotoneaster species. - Acta Fytotechn. Zootechn. 23(1): 15-23. DOI: 10.15414/afz.2020.23.01.15-23 
Marhold K., Mártonfi P., Mered’a P. jun. \& Mráz P. (Eds) (2007): Chromosome number survey of the ferns and flowering plants of Slovakia. - Veda, Bratislava. $650 \mathrm{pp}$.

Medvecká J., Kliment J., Májeková J., Halada L., Zaliberová M., Gojdičová E., Feráková V. \& Jarolímek I. (2012): Inventory of the alien flora of Slovakia. - Preslia 84: 257-309.

Mikoláš V. (1988): Brachyactis ciliata (Ledeb.) Ledeb., eine für die Tschechoslowakei neue Art einer Blütenpflanze. - Biológia (Bratislava) 43/9: 841-848.

Mirek Z., Piękoś-Mirkowa H., Zając A. \& Zając M. (2002): Flowering plants and pteridophytes of Poland, a checklist. - W. Szafer Institute of Botany, Polish Academy of Sciences. Kraków, 442 pp.

Morales R. \& Luque M. N. (1997): El género Calamintha Mill. (Labiatae) en la Península Ibérica e Islas Baleares. - An. Jará. Bot. Madrid 55(2): 261-276.

Nobis M. \& Nobis A. (2006): Interesujące, rzadkie i rozprzestrzeniające się gatunki roślin naczyniowych notowane na terenach kolejowych w południowo-wschodniej Polsce. Fragm. Flor. Geobot. Polonica 13(2): 301-308.

Nobis M. \& Pliszko A. (2016): New localities of Symphyotrichum ciliatum (Asteraceae) in Poland. - Acta Mus. Siles. Sci. Natur. 65: 283-286. DOI: 10.1515/cszma-2016-0036

Nobis M., Klichowska E., Terlević A., Wróbel A., Erst A., Hrivnák R., Ebel A. L., Tikhomirov V. N., Byalt V. V., Gudkova P. D., Király G., Kipriyanova L. M., Olonova M., Piwowarczyk R., Pliszko A., Rosadziński S., Seregin A. P., Honcharenko V., Marciniuk J., Marciniuk P., Oklejewicz K., Wolanin M., Batlai O., Bubíková K., Choi H. J., Dzus M. A., Kochjarová J., Molnár A. V., Nobis A., Nowak A., Otáahel'ová H., Óvári M., Shimko I. I., Shukherdorj B., Sramkó G., Troshkina V. I., Verkhozina A. V., Wang W., Xiang K. \& Zykova E. Y. (2019): Contribution to the flora of Asian and European countries: new national and regional vascular plant records 8. - Bot. Lett. 166/2: 163-188. doi.org/10.1080/23818107.2019.1600165

Nowak A. \& Nowak S. (2018): Nowe stanowiska interesujących halofitów wzdłuż autostrady A4 na Śląsku Opolskim. - Fragm. Nat. 51: 79-83.

Pahlevani A. H. \& Riina R. (2011): A synopsis of Euphorbia subgen. Chamaesyce (Euphorbiaceae) in Iran. - Ann. Bot. Fen. 48/4: 304-316. DOI: 10.5735/085.048.0402

Plants of the Word online (2020): Clinopodium nepeta subsp. nepeta. Published on the internet

https://www.plantsoftheworldonline.org/taxon/urn:Isid:ipni.org:names:77167928-1 [accessed 22 September 2020].

Pliszko A. (2017) A new record of Senecio inaequidens (Asteraceae) in Poland. - Acta Mus. Siles. Sci. Natur. 66: 177-180. DOI: 10.1515/cszma-2017-0022

Pyšek P., Danihelka J., Sádlo J., Chrtek J. Jr., Chytrý M., Jarošík V., Kaplan Z., Krahulec F., Moravcová L., Pergl J., Štajerová K. \& Tichý L. (2012): Catalogue of alien plants of the Czech Republic (2nd edition): checklist update, taxonomic diversity and invasion patterns. Preslia 84: 155-255.

Randall R. P. (2017): A Global Compendium of Weeds. 3rd edition. - R. P. Randall - Western Australia, Perth, 3654 pp.

Rozporządzenie Ministra Środowiska z dnia 9 października 2014 r. w sprawie ochrony gatunkowej roślin. Dz.U. 2014 poz. 1409.

Rutkowski L. (2004): Klucz do oznaczania roślin naczyniowych Polski niżowej. - Wydawnictwo Naukowe PWN. - Warszawa, 814 pp.

Ružičková J., Lehotská B., Takáčová A. \& Semerád M. (2020): Morphometry of alien species Pistia stratiotes L. in natural conditions of the Slovak Republic. - Biologia 75: 1-10. doi.org/10.2478/s11756-019-00345-5 
Sadowska A. \& Żółkoś K. (2011): Antropogeniczne stanowisko babki pierzastej Plantago coronopus L. w Gdańsku. - Acta Bot. Cassub. 10: 107-114.

Sârbu A. \& Smarandache D. (2015): Symphyotrichum ciliatum an invasive species in the Romanian flora - contributions to the knowledge of the vegetative organs structure. Acta Horti Bot. Bucurest. 42: 5-22. DOI: 10.1515/ahbb-2015-0004

Schmotzer A. (2015): Occurrence of Lindernia dubia (L.) Pennell in the Ipoly valley (Hungary and Slovakia). - Studia Bot. Hung. 46: 77-89. DOI: 10.17110/StudBot.2015.46.1.77

Sotek Z. (2014): Plantago coronopus L. - In: Kaźmierczakowa R., Zarzycki K. \& Mirek Z. (eds.), Polska czerwona księga roślin. Paprotniki i rośliny kwiatowe. - Instytut Ochrony Przyrody, Polska Akademia Nauk. - Kraków, pp. 485-487.

Stadnicka-Futoma A. \& Oklejewicz K. (2013): Nowe stanowisko Symphyotrichum ciliatum (Asteraceae) na Przedgórzu Rzeszowskim. - Fragm. Flor. Geobot. Polonica 20(2): 386388.

Sutorý K. (1980): Rozšíření druhů rodu Herniaria L. v Československu. - Čas. Mor. Muz., Vědy Prír., Brno, 65: 57-70.

Szymański W. (2010): Nowe stanowiska Symphyotrichum ciliatum (Asteraceae) w Polsce. Fragm. Flor. Geobot. Polonica 17(2): 415-416.

Šlenker M., Zozomová-Lihová J. \& Marhold K. (2019): Cardamine occulta - nenápadný neofyt Slovenska. - Bull. Slov. Bot. Spoločn. 41: 13-23.

Thiers B. (2020+) [continuously updated]: Index Herbariorum: A global directory of public herbaria and associated staff. - New York Botanical Garden's Virtual Herbarium, New York. - Published at http://sweetgum.nybg.org/ih

Tokarska-Guzik B., Dajdok Z., Zając M., Zając A., Urbisz A., Danielewicz W. \& Hołdyński C. (2012): Rośliny obcego pochodzenia w Polsce ze szczególnym uwzględnieniem gatunków inwazyjnych. - Generalna Dyrekcja Ochrony Środowiska. - Warszawa, 197 pp.

Tóthová L., Ružičková J. \& Baláži P. (2011): Nový rastlinný druh na Slovensku - má potenciál byt' invázny? - Vodohospod. spravod. 11-12: 33.

Urbisz A. (2019): Nowe stanowisko Euphorbia maculata (Euphorbiaceae) w Polsce. - Fragm. Flor. Geobot. Polonica 26(1): 173-176.

Verloove F. (2013): Euphorbia. Manual of the alien plants of Belgium. Published on the internet https://alienplantsbelgium.be/content/euphorbia [accessed 12 October 2020].

Zając A. \& Zając M. (eds.) (2019): Distribution atlas of vascular plants in Poland: appendix. Institute of Botany, Jagiellonian University. - Kraków, 319 pp. 